tainly indisposed to throw away any more time on this discussion; but I may remind those who are interested in it that the question really lies between Prof. Newton and the Royal Commissioners. On the one hand, Prof. Newton, with no practical acquaintance with the subject, knowing nothing of the witnesses or of the circumstances under which they gave their evidence, but taking the Index to the evidence as his sole guide, so completely satisfied himself that the Commissioners had arrived at an erroneous conclusion in believing our sea-fisheries were flourishing that he brought their delinquencies before the British Association. On the other hand, Prof. Huxley (who somehow has obtained the character of thoroughly working out any subject he takes up, so far as he has the means of doing so) and the other Commissioners themselves visited the several fishery stations, ascertained beforehand the nature of the disputes and complaints among the fishermen, and examined and cross-examined the various witnesses. They spent many days separately and together in considering the evidence on the several subjects of their report, and unanimously agreed to this among other conclusions :-

"The total supply of fish obtained upon the coasts of the United Kingdom has not diminished of late years, but has increased ; and it admits of further augmentation to an extent the limits of which are not indicated by any evidence we have been able to obtain."

Athenæum Club, November 25

\section{Examinations in Science}

MAY I beg you will introduce to the notice of your readers a grievance urgently in need of a remedy? The grievance is considerable; the remedy simple; and if scientific men; will not make it their concern, nobody else will.

$\Lambda$ short time ago, when the competitive examination controversy waxed warm, I ventured to enter somewhat fully into the present haphazard system of awarding marks to candidates who competed for posts in the public service. My object then was twofold : - . (a) to bring facts and figures to bear against the erroneous statements of a few theorists who unfortunately were able to command a great deal of public attention; $(b)$ to get fair play for all examinees. My object now, however, is to warn those who advocate the advancement of scientific instruction, that the present faulty method of conducting public examinations (in some quarters at least) tends far more to the depression than to the encouragement of scientific study. Destitute myself of scientific knowledge, and bound to no particular curriculum of instruction, $\mathrm{I} \mathrm{am}$ obviously not writing from the point of view of a partisan; and if $I$ have joined in the lament of scientific men that insufficierit consideration is given in most schools to the teaching of science, it is simply because there are good grounds for the conviction that the higher education of this country is too one-sided.

The point I wish to raise is not whether the grammar and philosophy of science contribute to the training and stimulating of the youthful mind in a greater or less proportion than the grammar and ornaments of the Latin and Greek languages; nor whether so-called technical instruction is being properly administered or injudiciously shelved; but I am asking whether scientific teaching, so however little it be, is adequately encouraged by scientific men in the persons of their public examiners?

Judging from the issues of certain examinations, the candidates for which are drawn from the leading schools, I am satisfied that it is not.

By dint only of considerable pressure are candidates induced nowadays to carry on their school course in science for an additional year or two, so general is the conviction among them that they are merely gambling for marks and that the object of much honest labour will not be attained. In fact, for the particular purposes they have in view, they run the double risk of wasting their time and burning their fingers.

It may, of course, be urged that the ends of science are not furthered by youths $\mathrm{u}$ ho aspire to touch only a modest limit in view of qualifying for public employment; but surely as much may be said of almost every other branch of study. And if this is really the opinion entertained by science examiners, it would be better at once to expunge all scientific subjects from the Government programmes.

But candidates and teachers are concerned only with the rules and regulations that are actually current, and that wiser men have made; and their grievance is that there is a greater element of uncer- tainty in the azwards issued for science than for any other subject. Instead of estimating the various science subjects as fractional parts of a wide and comprehensive programme, and of dispensing marks on a fixed and definite plan whereby a given quota of proficiency shall be made to carry the same relative weight as a given quota of proficiency in other branches, it would seem that examiners, who, by the way, are constantly being changed, regard their own branch as a distinct entity- set up their own standard of excellence for the nonce-and distribute basket after basket of ducks' eggs among all who fail to reach a very advanced qualifying minimum, forgetting perhaps that meanwhile the classical candidate is receiving his modest or substantial reward according to the character of his work. The position indeed would be pretty much the same as if a classical examiner should announce that no candidate would be entitled to a single mark who did not write a faultless copy of Greek verses! I am prepared to show that this ideal standard has varied to the extent of 50 pei cent. in two successive years; nay, more, that science candidates have suffered a loss of 50 per cent. in their marks after an additional year's reading under the best teaching that money can purchase. A case occurred some months ago of a youtin who, having won the Huxley and Balfour prizes in Edinburgh, entered his name for an open competitive examination in London. He obtained 64 out of $I, 000$ marks in his two branches of science, at a moment when from 500 to 600 marks out of a total of $\mathrm{I}, 500$ were being showered upon the classical men. At this particular ordeal "Chemistry" chanced to receive decent recognition, but as this youth's tastes happened to run in another direction he was ignominiously defeated.

Any number of such cases may be enumerated, but perhaps I have said enough to prove that a real grievance does exist.

The remedy is obvious: either to induce the authorities to strike out the words "Natural Science" from their list of subjects, or to arrange for the formation of a committee of science examiners who will devise some plan for tixing, as nearly as possible, a uniform standard, and for distributing marks on equitable principles, after consultation with the classical, mathematical, and other examiners. In default of this I do not hesitate to say that examinees will continue to be trifled with at the most important crisis of their lives; for at these public examinations it is no longer a question whether they gain a scholarship or improve their position at school-it is a question of their future career.

I have yet to state the main point. Setting aside the fact of hardstip and injustice, it may be asked how far the present independent and very summary system of dealing with batches of schoolboys can possibly cripple the cause of the technicists who are anxious to press forward the teaching of science. My reply is that science candidares, heartsick wirh disappointment, will fall out of the ranks and will induce others not to enter them; the belief will rapidly gain ground in the schools that science is " a mistake ;" and there is abundant reason for supposing that many a schoolmaster will be only too willing to endorse this opinion. I contend that our public examiners wield the thong that lashes the schools into action, and that we are only just beginning to get fair play for what are called "modern" subjects, but that unless our science examiners apportion their marks in a more just and consistent manner they will simpiy drive all science candidates " bag and baggage" out of the field. In other words, they will virtually be paying a premium to the schoolmasters for neglecting to carry out the very objects they are clamouring for.

Garrick Chambers, Garrick Street, W. BAPTISTE SCOUNES

December I2

\section{The Rocks of Charnwood Fores}

MAX I be allowed a short space in reply to Prof. Hull's courteous reference to my letter on the Charnwood rocks, for I fear that I have failed to make two points in that sufficiently clear? One was, that as the Borrowdale series of the Lake District and the (Lower) Cambrian series of North Wales are equally azoic, no correspondence in time with the latter could be inferred for the azoic Charnwood rocks. The argument from absence of fossils surely tells as much one way as the other; indeed, having regard to the similar petrological conditions of the Borrowdale and Charnwood rocks, I think it is slightly in favour of their correspondence. The other point was, that as Prof. Sedgwick's term Cambrian included the Cambrian and Lower Silurian of the survey, his authority could not be quoted in favour of the (Lower) Cambrian age of the Charnwood rocks any more than of their correspondence with the Borrowdale series,-unless it could be 